\title{
Activity of preclinical and phase I clinical trial of a novel androgen receptor antagonist GT0918 in metastatic breast cancer
}

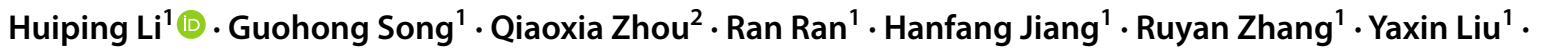 \\ Jiayang Zhang ${ }^{1} \cdot$ Luping Meng $^{2} \cdot$ Liandong $\mathrm{Ma}^{2} \cdot$ Ye Sun ${ }^{2} \cdot$ Meiyu Wang $^{2}$. Qingqing Zhou ${ }^{2} \cdot$ Honghua Yan $^{2}$. \\ Qianxiang Zhou ${ }^{2} \cdot$ Xunwei Dong $^{2} \cdot$ Youzhi Tong $^{2}$
}

Received: 24 May 2021 / Accepted: 29 July 2021 / Published online: 14 August 2021

(c) The Author(s) 2021

\begin{abstract}
Purpose To evaluate GT0918, a 2nd-generation AR antagonist, for its AR down-regulation activity among breast cancer patients.

Methods The effect of GT0918 on AR protein expression was evaluated in AR expression breast cancer cells and in breast cancer xenograft model. A $3+3$ phase I dose-escalation study was launched in Peking University Cancer Hospital. The endpoints included dose finding, safety, pharmacokinetics, and antitumor activity.

Results GT0918 was demonstrated to effectively suppress the expression of AR protein and the growth of AR-positive breast cancer tumors in mouse xenograft tumor models. All patients treated with GT0918 were at a QD dose-escalation of five dose levels from 100 to $500 \mathrm{mg}$. The most common treatment-related AEs of any grade were asthenia, anemia, decreased appetite, increased blood cholesterol, increased blood triglycerides, decreased white blood cell count, and increased lowdensity lipoprotein. Grade 3 AEs were fatigue ( 2 of 18, 11.1\%), aspartate aminotransferase increase (1 of 18, 5.6\%), alanine aminotransferase increase ( 1 of 18,5.6\%), and neutrophil count decrease ( 1 of 18, 5.6\%). Clinical benefit rate (CBR) in 16 weeks was $23.1 \%$ (3/13). Among 7 AR-positive patients, 6 can evaluate efficacy, and 2 completed 23.5- and 25-cycle treatment, respectively (as of 2020/1/20). PK parameters showed a fast absorption profile of GT0918 in the single-dose study. GT0918 and its major metabolite reached steady-state serum concentration levels at day 21 after multiple dosing.

Conclusion GT0918 can effectively inhibit AR-positive breast cancer tumor growth. GT0918 was demonstrated well tolerated with a favorable PK profile. The suitable dose of GT0918 was $500 \mathrm{mg}$ QD and may provide clinical benefits for ARpositive $\mathrm{mBC}$.
\end{abstract}

Keywords Androgen receptor antagonist $\cdot$ Proxalutamide $\cdot$ GT0918 $\cdot$ Metastasis breast cancer $\cdot$ Preclinical data $\cdot$ Phase I clinical trial

Huiping Li, Guohong Song, Ran Ran and Qiaoxia Zhou have contributed equally to this work.

Huiping Li

huipingli2012@hotmail.com

Youzhi Tong

yztong@kintor.com.cn

1 Key Laboratory of Carcinogenesis and Translational Research (Ministry of Education/Beijing), Department of Breast Oncology, Peking University Cancer Hospital \& Institute, 52 Fucheng Rd, Haidian district, Beijing 100142, People's Republic of China

2 Kintor Pharmaceutical Limited, No. 20 Songbei Road, Suzhou Industrial Park, Jiangsu 215123, People's Republic of China

\section{Introduction}

The activation of androgen receptor (AR) signaling plays a critical role in driving the initiation and progression of prostate cancer (1). AR-targeted drugs have been approved to treat prostate cancer only. However, accumulated clinical data have supported the potential clinical benefits of AR-targeted therapies for the treatment of patients with breast cancer (2). Recent studies have shown the correlation between AR pathway activation and breast cancer growth, suggesting that AR pathway is a potential therapeutic target for the breast cancer treatment (3-5). Breast cancer can be categorized into different subgroups according to its hormone receptor (HR) and human epidermal growth factor 2 
(HER2) status. AR has been identified in 70-90\% of ERpositive tumors $(6,7)$. AR may play different roles in breast cancer progression depending on the HR or HER2 amplification status (8-10). In the ER + AR + breast cancer cells, AR-ligand complex binds to estrogen-related element (ERE) in the nucleus and leads to cell apoptosis (11). On the other hand, in the ER-AR + breast cancer cells, AR complex binds to androgen-related element (ARE) in the nucleus and leads to cell proliferation (12). This hypothesis can explain why patients with ER-positive and AR-positive breast cancer have better prognosis than patients with ER-negative and AR-positive breast cancer $(13,14)$.

AR has been identified in $10 \%-35 \%$ of triple-negative breast cancer (TNBC) (15-17). The first-generation AR antagonist, bicalutamide, binds to AR-ligand binding domain (AR-LBD) and inhibits its transcriptional activities (18). A phase II clinical trial evaluating bicalutamide in patients with AR-positive, ER/PR-double-negative metastatic breast cancer showed a 6-month clinical benefit rate (CBR) of $19 \%$ (15). Enzalutamide, a 2nd-generation AR antagonist, has also been assessed in several studies in TNBC patients and has shown clinical benefits in patients with TNBC treatment, as shown a 16 -week CBR of $35 \%$ and a 24 -week CBR of 29\% (16, 19-21). Hence, AR-targeted therapies could be potential treatments for this most aggressive breast cancer subtype. The safety, tolerability, and drug-drug interaction of enzalutamide had been also evaluated, as a mono or in combination with endocrine therapies (ETs), in a recent phase I/Ib clinical trial in patients with advanced breast cancer. Results from this study demonstrated that enzalutamide used as mono or in combination with ETs were well tolerated (22).

Here, we reported the preclinical and clinical data of GT0918 in mBC, including in vitro and in vivo activities of GT0918 in AR-positive metastatic breast cancer models and phase I study results in $\mathrm{mBC}$ (safety, efficacy, and pharmacokinetic properties). Our data suggest that GT0918 may have therapeutic benefits in patients with $\mathrm{mBC}$.

\section{Materials and Methods}

\section{Preclinical studies}

\section{Study cell lines and cell culture}

Human Breast cancer lines, MCF-7, BT-474, and MDAMB-468, were obtained from culture collection of Chinese Academy of Sciences, Shanghai, China. The MCF-7 and MDA-MB-468 cells were cultured in DMEM supplemented with $10 \%$ fetal bovine serum and the BT474 was cultured in RPMI1640 supplemented with $10 \%$ fetal bovine serum.
The cells were cultured in incubator containing 95\% air and $5 \% \mathrm{CO}_{2}$ at $37^{\circ} \mathrm{C}$.

\section{Breast cancer xenograft tumor model}

The 6-8 weeks old female BALB/c nude mouse (SPF grade, 18-20 g) was provided by Vital River Laboratory Animal Technology (Beijing, China). Mouse was supplemented with $1.7 \mathrm{mg}$ E2-pellets (90-day release, Innovative Research of America). MCF-7 ( $1.5 \times 10^{7}$ cells $)$ BT-474 ( $1.5 \times 10^{7}$ cells $)$, and MDA-MB-468 $\left(1.5 \times 10^{7}\right.$ cells $)$ breast cancer cells were suspended in $200 \mu \mathrm{L}$ of PBS with $50 \%$ Matrigel, and then, the cells were injected orthotopically into the right axial mammary gland to initiate tumor growth. The mouse was then divided ( $n=8$, each group). The mouse was given daily oral dose of GT0918 (5 mg/kg, $10 \mathrm{mg} / \mathrm{kg}, 20 \mathrm{mg} / \mathrm{kg}$, and $40 \mathrm{mg} / \mathrm{kg} \mathrm{BID}$ ) or MDV3100 (20 mg/kg BID) for 21 days, and $8 \mathrm{mg} / \mathrm{kg}$ of cisplatin was injected intraperitoneally once weekly. The body weight and the tumor size were measured twice a week using caliper and tumor volume were calculated according the formula: $\mathrm{L} \times \mathrm{S} 2 \times 0.5$, in which $\mathrm{L}$ represents the longest diameter and $\mathrm{S} 2$ represents the shorter diameter of tumor.

\section{Clinical study}

\section{Study design and treatment}

This was a phase I, open-label, dose-escalation, and singlecenter study performed at Peking University Cancer Hospital, China. The study was conducted in accordance with the principles of the Declaration of Helsinki, Good Clinical Practice, applicable laws and requirements. The study protocol was reviewed and approved by the ethics review committee of Peking University Cancer Hospital. All patients were given a written informed consent, and this trial was registered in ClinicalTrials.Gov (NCT04103853).

The primary objective endpoints were the safety, the maximum-tolerated dose (MTD), the recommended dose for expansion (RDE), and dose-limiting toxicities (DLTs) of oral GT0918 in female mBC patients with progression after systemic treatments. The secondary objectives were pharmacokinetics and pharmacodynamics of GT0918 with single and multiple dosages.

The starting dose was $100 \mathrm{mg}$ daily, followed by doseescalation of 200, 300, 400, and $500 \mathrm{mg}$. The dose-escalation, in $3+3$ design, was determined by the safety and tolerability assessments. GT0918 was administered orally once daily, followed by a 7-day off treatment period for singledose PK analysis of drug elimination. Then, the oral administration of GT0918 was resumed once daily for 28 consecutive days and multiple-dose PK analysis was assessed at the end of first cycle ( 28 days). The first 28 days on treatment 
(cycle 1) was defined as DLT period. Patients with an objective response, stable disease, or potential clinical benefit continued the GT0918 treatment until they experienced one of following events of intolerable toxicities, disease progression, or withdrew consent.

\section{Study population}

Eligible patients were $\geq 18$ years old women with an Eastern Cooperative Oncology Group (ECOG) performance status of $0-1$ and with histologically confirmed metastatic breast cancer (defined for ER, PR, and human epidermal growth factor receptor by IHC or by in situ hybridization. AR status was suggested to be confirmed). All patients had been progressing after either chemotherapy, hormonal or targeted therapy, or could not tolerate currently standard treatment. Additional eligibility criteria included measurable disease per the Response Evaluation Criteria in Solid Tumors (RECIST 1.1) and adequate hematologic, coagulation, renal, and liver function.

Exclusion criteria included treatments of chemotherapy, radiotherapy, targeted therapy, endocrine therapy, and Chinese traditional medicine therapy in 4 weeks prior the enrollment. Patients were ineligible for enrollment if they had known or suspected central nervous system (CNS) metastases or had a history of seizure, significant cardiovascular disease.

\section{Safety assessments}

The safety assessments were performed in all patients who received at least one dose of GT0918. Safety was determined by assessment of adverse events (AEs), vital signs, physical examination, 12-lead electrocardiograms, echocardiography, and laboratory tests during the time periods of the first GT0918 dose until 30 days after the last dose. The severity of AEs and abnormal laboratory values were graded using NCI CTCAE version 4.03.

\section{PK Assessments}

A series of blood samples were collected from each patient for pharmacokinetic analysis at the following timings: PK after single dose: 0 (predose) and at $0.5,1,2,3,4,5,6,8$, $12,24,48,72,96,120$, and $144 \mathrm{~h}$ postdose on Day 1 , and PK after multiple dosing: 0 (predose) and at 0.5, 1, 2, 3, 4, $5,6,8,12$, and $24 \mathrm{~h}$ postdose on Day 28. In addition, pretreatment samples were collected on days $3,5,7,14$, and 21 during cycle 1 .

PK analysis for all parameters was performed using Phoenix WinNonlin (Pharsight Corporation, a Certara ${ }^{\mathrm{TM}}$ Company, version 8.1) with standard noncompartmental analysis methods. Parameters analyzed included maximum observed plasma concentration $\left(C_{\max }\right)$, time of maximum observed plasma concentration $\left(T_{\max }\right)$, area under the plasma concentration-time curve (AUC) from time 0 to time of last quantifiable concentration $\left(\mathrm{AUC}_{0-\mathrm{t}}\right)$ and $\mathrm{AUC}$ from time 0 to $24 \mathrm{~h}$ postdose $\left(\mathrm{AUC}_{0-24}\right)$, terminal elimination half-life (T1/2), apparent total clearance of the drug (CL/F), and apparent volume of distribution $(\mathrm{Vz} / \mathrm{F})$.

\section{Antitumor activity}

Assessment radiographic responses were performed with radiographic scan at baseline, and every 8 weeks or earlier if clinically indicated. Tumor responses were defined by RECIST version 1.1 criteria.

\section{Statistical analysis}

All patients receiving at least one dose of GT0918 were included in the analysis. During dose-escalation, the number of patients enrolled in each dose-escalation cohort depended on the observed safety status. MTD was defined as the highest dose tested with at least 6 patients evaluable for toxicity of which fewer than 33\% experienced a DLT due to the study drug. For PK analysis, all available PK data from patients receiving GT0918 with adequate concentration distribution were included. Descriptive statistics were used to assess patient characteristics, safety, PK parameters, and anti-tumor activity.

\section{Results}

\section{The antitumor effect of GT0918 on breast cancer tumors in xenograft models}

We evaluated the antitumor effect of GT0918 in AR-positive MCF-7 and BT474 breast cancer xenograft tumors. As shown in Fig. 1A, B, GT0918 significantly inhibited the AR-positive MCF-7 and BT474 tumor growth. Compared with MDV3100, GT0918 demonstrated better antitumor activities. In contrast, GT0918 showed no antitumor activity in AR-negative MDA-MB-468 breast cancer xenograft tumors (Fig. 1C). The GT0918-treated groups did not show any body weight change at the tested dosage (Fig. 1A-C), suggesting that GT0918 was not toxic in vivo. These results demonstrate that GT0918 selectively inhibits the growth of estrogen-driven/AR-positive breast cancer tumors with no activity in AR-negative breast cancer tumor model.

\section{Patient characteristics and disposition}

From September 6, 2017 through May 22, 2019, 18 patients were enrolled and treated in the QD 
Fig. 1 The antitumor effect of GT0918 on breast cancer xenograft model. A Effect of GT0918 on MCF-7 xenograft models. B Effect of GT0918 on BT474 xenograft models. C Effect of GT0918 on MDAMB-468 xenograft models. The volume of each tumor was measured every 3 days. The average tumor volume in the vehicle, GT0918, MDV-3100, or Cisplatin-treated group was plotted $(* * p<0.01$, compared to control)

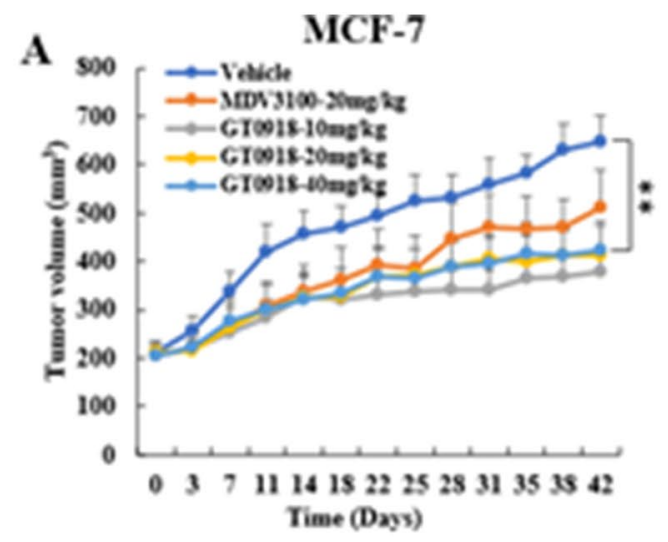

B
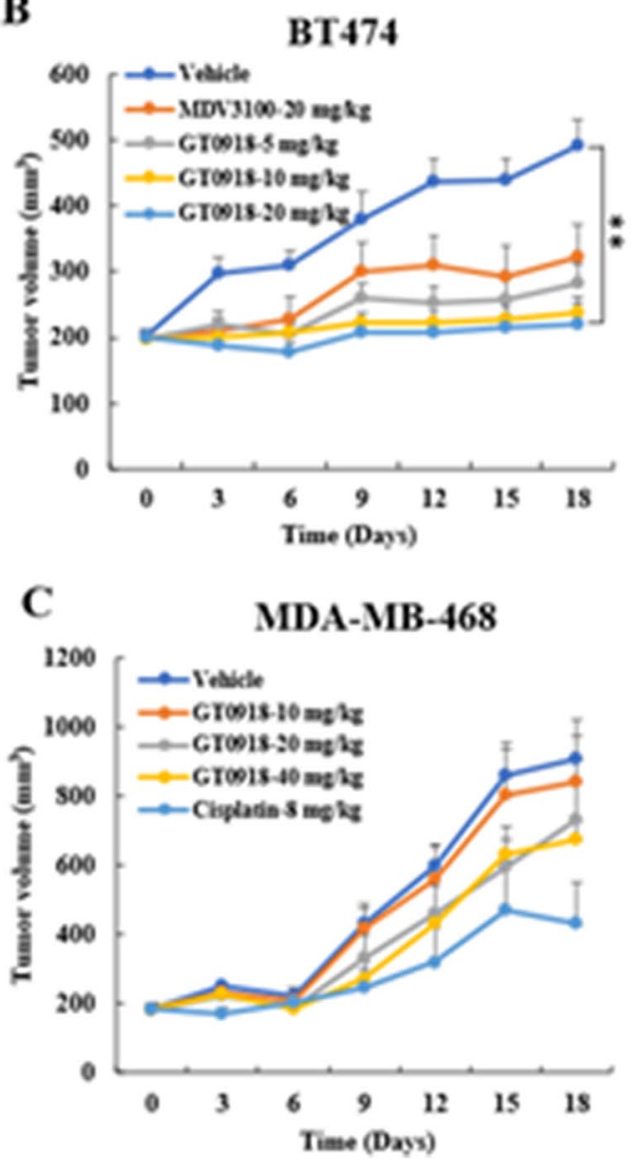

MCF-7

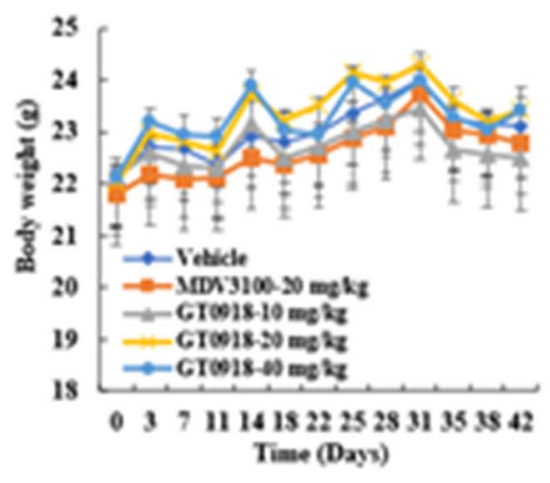

\section{BT474}

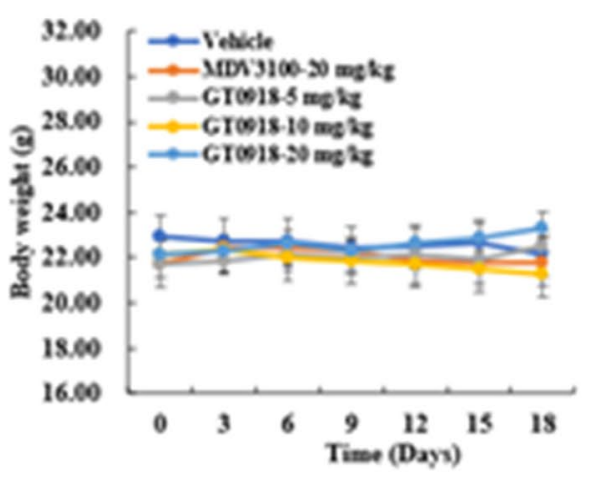

MDA-MB-468

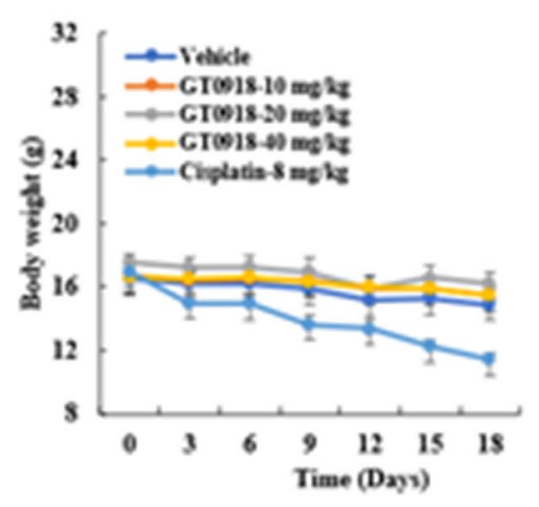

dose-escalation. There were 26 patients who entered the study, and 8 failed screening criteria (Fig. 2). Table 1 shows demographic and other baseline disease characteristics of the 18 patients enrolled from the site in China. All the 18 patients had experienced surgery for cancer and systemic therapies previously: chemotherapy (18 patients; $100 \%$ ), hormonal therapy (12 patients; $66.7 \%$ ), or targeted therapy (12 patients; $66.7 \%$ ); the most frequently reported treatments were $\geq 3$ regimens ( 15 patients; $83.3 \%$ ). A total of ten patients $(55.6 \%)$ received radiation therapies.
The data cut-off date occurred on January 20, 2020. The median age of patients was 56 (range, 35-66). Most patients $(94.4 \%)$ had an ECOG PS of 0 , and $5.6 \%$ had an ECOG PS of 1 at baseline. Overall, 16.7\% (3 of 18 patients) had HER2-positive disease, $16.7 \%$ (3 of 18 patients) were triple-negative, $77.8 \%$ (14 of 18 patients) had HR-positive disease, and $38.9 \%$ (7 of 18 patients) had AR-positive disease. 


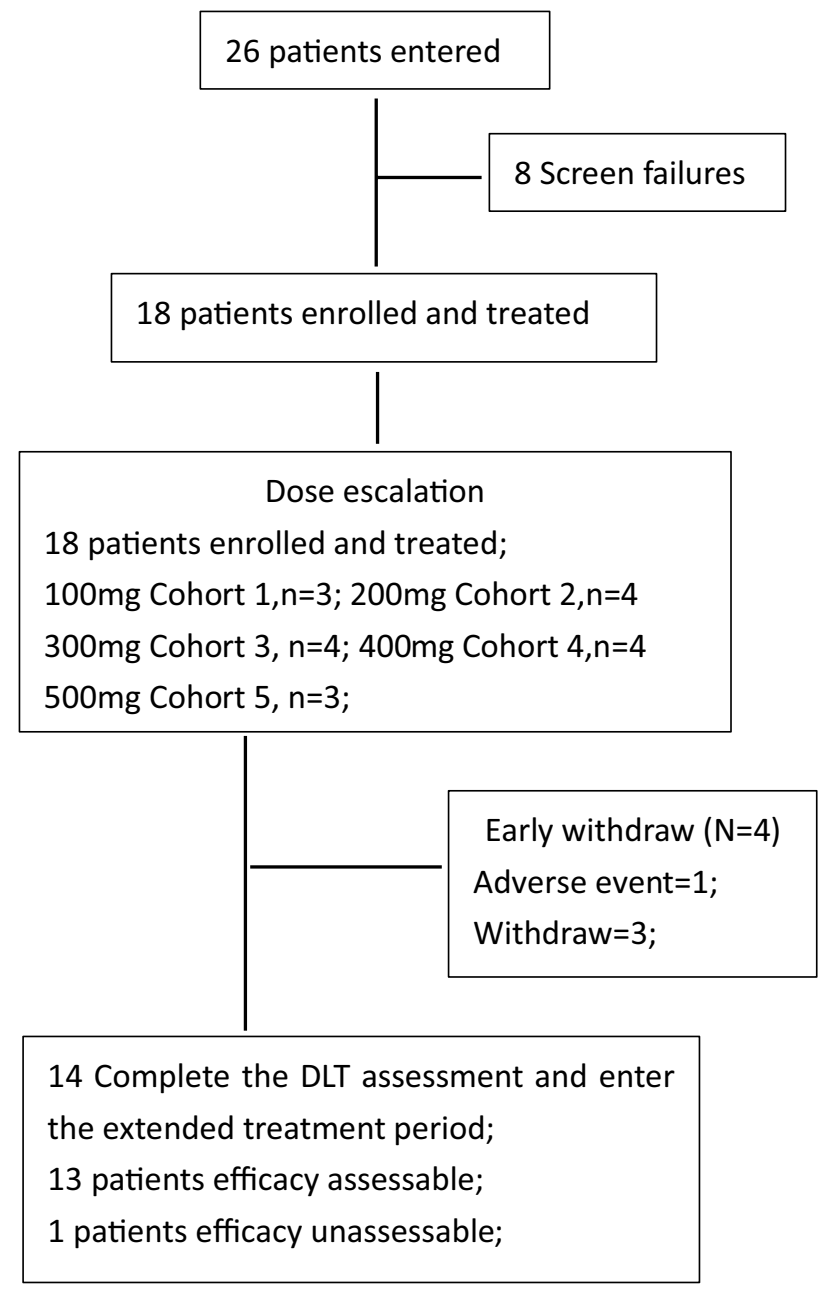

Fig. 2 Study diagram

\section{Dose-escalation}

18 patients in total were enrolled in the study: 3 patients in $100 \mathrm{mg}, 500 \mathrm{mg}$ group, respectively, and 4 patients in $200 \mathrm{mg}, 300 \mathrm{mg}$, or $400 \mathrm{mg}$ group, respectively. 14 patients were evaluable for DLT ( 1 experienced progressive disease and 3 withdrew from the study during DLT assessment period). No DLT was observed and MTD has not been reached. Patients complain fatigue and upset but did not reach DLT in $400 \mathrm{mg}$ and $500 \mathrm{mg} /$ day groups. Thus, GT0918 $200 \mathrm{mg}$ and $300 \mathrm{mg} /$ day were selected for further testing.

\section{Safety}

All patients were evaluable for safety analysis. Table 2 summarizes all grades of treatment-related AEs occurring in $>10 \%$ of patients. The most common non-hematological
AEs were asthenia ( 13 of $18,72.2 \%$ ), fatigue ( 2 of $18,11.1 \%$ ), anemia (6 of 18, 33.3\%), decreased appetite ( 4 of $18,22.2 \%$ ), nausea ( 3 of $18,16.7 \%)$, constipation ( 3 of 18, 16.7\%), weight loss ( 3 of $18,16.7 \%)$, increased blood cholesterol (8 of $18,44.4 \%$ ), increased blood triglycerides increase ( 6 of $18,33.3 \%)$, increased aspartate aminotransferase (4 of 18 , $22.2 \%$ ), increased low-density lipoprotein (4 of 18, 22.2\%), and increased alanine aminotransferase ( 3 of 18, 16.7\%). The most common hematological AEs were decreased white blood cell count ( 4 of $18,22.2 \%$ ), neutrophil count ( 2 of $18,11.1 \%$ ), and platelet count ( 2 of $18,11.1 \%$ ). These AEs were mainly grade 1-2 and were manageable with supportive care and dose reduction. Grade 3 AEs were fatigue (2 of $18,11.1 \%$ ), aspartate aminotransferase increase ( 1 of 18 , $5.6 \%$ ), alanine aminotransferase increase (1 of $18,5.6 \%$ ), and neutrophil count decrease ( 1 of $18,5.6 \%$ ). No treatmentrelated deaths or DLTs occurred.

One patient discontinued the treatment because of AST increase (during the first cycle) which was unlikely treatment-related with GT0918 and probably was related with the disease progression. A total of $5(27.8 \%)$ patients experienced SAEs (considered treatment-related in one patient, including asthenia and decreased appetite) 0.1 (5.6\%) patient died during this study; the primary cause of death for the patient was disease progression and was considered to be unrelated with the study drug. Patients complaining fatigue were more frequent in the $500 \mathrm{mg}$ group.

\section{Pharmacokinetics}

PKs were evaluated in 18 patients, and the PK parameters of GT0918 with single and consecutive administrations are shown in (Tables 3 and 4). The mean plasma concentration vs time profiles following a single dose and multiple doses are shown in Fig. 3. GT0918 was rapidly absorbed after oral administration, as the median time of maximum observed concentration $\left(T_{\max }\right)$ was between 1.02 and $3.01 \mathrm{~h}$ for single oral dose and between 0.00 and $5.13 \mathrm{~h}$ for multiple doses. With a single dosing at $100 \mathrm{mg}-500 \mathrm{mg}$ (Fig. 4), $C_{\max }$ was approximately 5.18, $7.4,1.51,1.27$, and $2.21 \mu \mathrm{g} / \mathrm{mL}$, and $\mathrm{AUC}_{0-\mathrm{t}}$ was 235,244 , 709,954 , and $1470 \mathrm{~h} \cdot \mu \mathrm{g} / \mathrm{mL}$, respectively. The steadystate serum concentration level of GT0918 was reached at 21 days in the multiple-dose study. Cmax, ss at Day 28, was 37.3, 50.9, 81.0, 82.7, and $151.0 \mu \mathrm{g} / \mathrm{mL}$, and $\mathrm{AUC}_{0-\mathrm{t}}$ was $731,1040,1640,1690$, and $2920 \mathrm{~h} \cdot \mu \mathrm{g} / \mathrm{mL}$, respectively. Drug exposure parameters including the area under the concentration-time curve (AUC) and maximum concentration $\left(C_{\max }\right)$ were increased with dose proportionally after a single dose and multiple doses ranging from 100 to $500 \mathrm{mg}$. The ratio of AUC from 0 to $24 \mathrm{~h}$ postdose $\left(\mathrm{AUC}_{0-24}\right)$ between day 28 after daily dosing and day 1 
Table 1 Patient demographic characteristics

\begin{tabular}{|c|c|c|c|c|c|c|c|}
\hline Parameter & Category/Statistic & $\begin{array}{l}100 \mathrm{mg} \\
(\mathrm{N}=3)\end{array}$ & $\begin{array}{l}200 \mathrm{mg} \\
(\mathrm{N}=4)\end{array}$ & $\begin{array}{l}300 \mathrm{mg} \\
(\mathrm{N}=4)\end{array}$ & $\begin{array}{l}400 \mathrm{mg} \\
(\mathrm{N}=4)\end{array}$ & $\begin{array}{l}500 \mathrm{mg} \\
(\mathrm{N}=3)\end{array}$ & $\begin{array}{l}\text { Total } \\
(\mathrm{N}=18)\end{array}$ \\
\hline \multirow[t]{4}{*}{ Age (year) } & $\mathrm{N}$ & 3 & 4 & 4 & 4 & 3 & 18 \\
\hline & Mean & $54.3(8.96)$ & $55.8(11.47)$ & $50.3(5.56)$ & $55.8(14.41)$ & $49.0(7.55)$ & $53.2(9.48)$ \\
\hline & Median & 59 & 60 & 50 & 61 & 50 & 56 \\
\hline & Min -Max & $44-60$ & $39-65$ & $45-56$ & $35-66$ & $41-56$ & $35-66$ \\
\hline \multicolumn{8}{|l|}{ Fertility, n(\%) } \\
\hline & $\mathrm{n}$ & 3 & 4 & 4 & 4 & 3 & 18 \\
\hline & Yes & $1(33.3 \%)$ & $1(25.0 \%)$ & $4(100 \%)$ & $1(25.0 \%)$ & $2(66.7 \%)$ & $9(50.0 \%)$ \\
\hline & No & $2(66.7 \%)$ & $3(75.0 \%)$ & 0 & $3(75.0 \%)$ & $1(33.3 \%)$ & $9(50.0 \%)$ \\
\hline & Menarche & 0 & 0 & 0 & 0 & 0 & 0 \\
\hline & Surgical sterilization & 0 & 0 & 0 & 0 & 0 & 0 \\
\hline & Menopause & $2(100 \%)$ & $3(100 \%)$ & 0 & $2(66.7 \%)$ & $1(100 \%)$ & $8(88.9 \%)$ \\
\hline & Others & 0 & 0 & 0 & $1(33.3 \%)$ & 0 & $1(11.1 \%)$ \\
\hline \multicolumn{8}{|l|}{ Treatment of Primary Tumor } \\
\hline & Surgery & $\begin{array}{l}2 \\
(66.7 \%)\end{array}$ & $\begin{array}{l}4 \\
(100 \%)\end{array}$ & $\begin{array}{l}3 \\
(75 \%)\end{array}$ & $4(100 \%)$ & $3(100 \%)$ & $16(88.9 \%)$ \\
\hline & Radiation & $3(100 \%)$ & $\begin{array}{l}3 \\
(75 \%)\end{array}$ & $\begin{array}{l}2 \\
(50 \%)\end{array}$ & $\begin{array}{l}1 \\
(25 \%)\end{array}$ & $1(33.3 \%)$ & $10(55.6 \%)$ \\
\hline \multirow[t]{3}{*}{ Prior Therapy } & Chemotherapy & $\begin{array}{l}3 \\
(100 \%)\end{array}$ & $4(100 \%)$ & $\begin{array}{l}4 \\
(100 \%)\end{array}$ & $\begin{array}{l}4 \\
(100 \%)\end{array}$ & $\begin{array}{l}3 \\
(100 \%)\end{array}$ & $\begin{array}{l}18 \\
(100 \%)\end{array}$ \\
\hline & Hormonal Therapy & $\begin{array}{l}3 \\
(100 \%)\end{array}$ & $\begin{array}{l}4 \\
(100 \%)\end{array}$ & $\begin{array}{l}1 \\
(25 \%)\end{array}$ & $\begin{array}{l}2 \\
(50 \%)\end{array}$ & $\begin{array}{l}2 \\
(66.7 \%)\end{array}$ & $\begin{array}{l}12 \\
(66.7 \%)\end{array}$ \\
\hline & Targeted Therapy & $\begin{array}{l}3 \\
(100 \%)\end{array}$ & 0 & $\begin{array}{l}4 \\
(100 \%)\end{array}$ & $\begin{array}{l}3 \\
(75 \%)\end{array}$ & $\begin{array}{l}2 \\
(66.7 \%)\end{array}$ & $\begin{array}{l}12 \\
(66.7 \%)\end{array}$ \\
\hline \multirow[t]{2}{*}{$\begin{array}{l}\text { Number of previous regimens } \\
\text { for advanced breast cancer }\end{array}$} & $<3$ & 0 & $\begin{array}{l}1 \\
(25 \%)\end{array}$ & $\begin{array}{l}1 \\
(25 \%)\end{array}$ & $\begin{array}{l}1 \\
(25 \%)\end{array}$ & 0 & $\begin{array}{l}3 \\
(16.7 \%)\end{array}$ \\
\hline & $\geq 3$ & $\begin{array}{l}3 \\
(100 \%)\end{array}$ & $\begin{array}{l}3 \\
(75 \%)\end{array}$ & $\begin{array}{l}3 \\
(75 \%)\end{array}$ & $\begin{array}{l}3 \\
(75 \%)\end{array}$ & $\begin{array}{l}3 \\
(100 \%)\end{array}$ & $\begin{array}{l}15 \\
(83.3 \%)\end{array}$ \\
\hline \multirow[t]{2}{*}{$\mathrm{AR}$} & $\mathrm{N}$ & 3 & 3 & 3 & 2 & 3 & 14 \\
\hline & AR positive & $\begin{array}{l}2 \\
(66.7 \%)\end{array}$ & $\begin{array}{l}2 \\
(66.7 \%)\end{array}$ & 0 & $\begin{array}{l}1 \\
(50 \%)\end{array}$ & $\begin{array}{l}2 \\
(66.7 \%)\end{array}$ & $\begin{array}{l}7 \\
(50 \%)\end{array}$ \\
\hline HER2 positive & & 0 & 0 & $\begin{array}{l}2 \\
(50 \%)\end{array}$ & 0 & $\begin{array}{l}1 \\
(33.3 \%)\end{array}$ & $\begin{array}{l}3 \\
(16.7 \%)\end{array}$ \\
\hline Triple-negative & & 0 & 0 & $\begin{array}{l}2 \\
(50 \%)\end{array}$ & 0 & $\begin{array}{l}1 \\
(33.3 \%)\end{array}$ & $\begin{array}{l}3 \\
(16.7 \%)\end{array}$ \\
\hline \multirow[t]{2}{*}{ ECOG } & 0 & $\begin{array}{l}3 \\
(100 \%)\end{array}$ & $\begin{array}{l}4 \\
(100 \%)\end{array}$ & $\begin{array}{l}4 \\
(100 \%)\end{array}$ & $\begin{array}{l}3 \\
(75 \%)\end{array}$ & $\begin{array}{l}3 \\
(100 \%)\end{array}$ & $\begin{array}{l}17 \\
(94.4 \%)\end{array}$ \\
\hline & 1 & 0 & 0 & 0 & $\begin{array}{l}1 \\
(25 \%)\end{array}$ & 0 & $\begin{array}{l}1 \\
(5.6 \%)\end{array}$ \\
\hline
\end{tabular}

after single dosing was from 8.35 to 11.0 , suggesting a drug accumulation after multiple dosing. Terminal halflife $\left(\mathrm{T}_{1 / 2}\right)$ ranged from 25.1 to $97.4 \mathrm{~h}$ across the dose levels for single administration. Mean apparent clearance values (CL/F) ranged from 0.217 to $1.1 \mathrm{~L} / \mathrm{h}$ for single administration and from 0.10 to $0.2 \mathrm{~L} / \mathrm{h}$ for consecutive administration, suggesting that the elimination of GT0918 was slow.

\section{Antitumor activity}

In the dose-escalation phase, 18 patients were exposed to study drug with doses ranging from 100 to $500 \mathrm{mg}$ QD on a 28-day cycle. All patients progressed from more than two lines of therapies, and $83.3 \%$ (15/18) patients progressed three lines or more. There were 13 patients can evaluate 


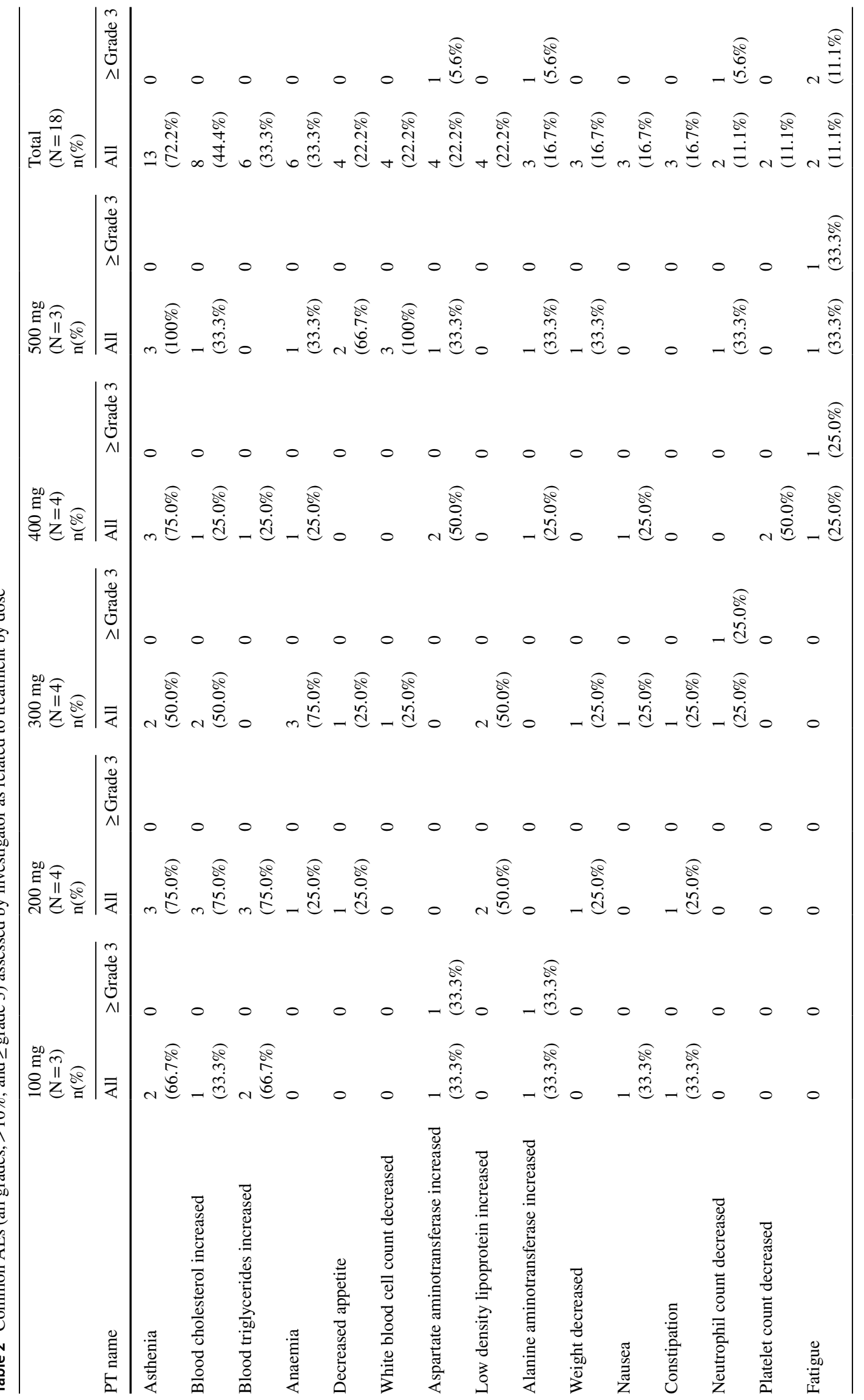


efficacy, four patients obtained SD (Fig. 5), 3 of them last more than 16 weeks; clinical benefit rate (CBR) in 16 weeks was $23.1 \%$. Out of the seven confirmed AR + patients, three got response: 1 was in $500 \mathrm{mg}, 8$ weeks treatment, and withdrew study because of fatigue; 2 in $200 \mathrm{mg}$ dose group; those two patients' lesions were obtained reduced SD, one patient was lung, pleural fluid, and bone metastasis, had 1 line chemotherapy (Docetaxel), 3 line endocrine therapy (Toremifene, Exemestane, Fulvestrant), she obtained 23.5 cycles; another one was liver and lung metastasis, experienced 1 line chemotherapy (docetaxel), 2 line endocrine therapy (Exemestane, Fulvestrant), she obtained 25 cycles
Table 3 GT0918 steady-state pharmacokinetics following 28 days of once-daily administration (geometric Mean $\pm \mathrm{CV} \%) * \mathrm{Tmax}:$ presented as Median (Min, Max)

\begin{tabular}{llllll}
\hline PK parameter & $\begin{array}{l}\text { Cohort 1 } \\
100 \mathrm{mg}\end{array}$ & $\begin{array}{l}\text { Cohort 2 } \\
200 \mathrm{mg}\end{array}$ & $\begin{array}{l}\text { Cohort 3 } \\
300 \mathrm{mg}\end{array}$ & $\begin{array}{l}\text { Cohort 4 } \\
400 \mathrm{mg}\end{array}$ & $\begin{array}{l}\text { Cohort 5 } \\
500 \mathrm{mg}\end{array}$ \\
\hline$C_{\max }(\mu \mathrm{g} / \mathrm{ml})$ & 37.3 & 50.9 & 81 & 82.7 & 151 \\
& 40 & 17.0 & 57.3 & 64.1 & 13.1 \\
$* T_{\max }(\mathrm{h})$ & 3.05 & 0.00 & 3.03 & 5.13 & 1.50 \\
& $(0.00,4.97)$ & $(0.00,3.98)$ & $(0.00,5.03)$ & $(1.88,8.12)$ & $(0.00,3.00)$ \\
Cavg $(\mu \mathrm{g} / \mathrm{ml})$ & 30.3 & 43.4 & 68.3 & 70.9 & 121 \\
& 37.6 & 25.3 & 59.2 & 64.0 & 16.5 \\
$\mathrm{AUC}_{\text {tau }}(\mathrm{h} * \mathrm{ug} / \mathrm{ml})$ & 728 & 1040 & 1640 & 1700 & 2910 \\
& 37.6 & 25.3 & 59.2 & 64.0 & 16.5 \\
\hline
\end{tabular}

Table 4 GT0918

pharmacokinetics parameters following a single dose administration (geometric mean $(\mathrm{CV} \%))$

\begin{tabular}{lllllll}
\hline & $t_{1 / 2}(\mathrm{~h})$ & $T_{\max }(\mathrm{h})$ & $C_{\max }(\mu \mathrm{g} / \mathrm{mL})$ & $\mathrm{AUC}_{0-\mathrm{t}}\left(\mathrm{h}^{*} \mu \mathrm{g} / \mathrm{mL}\right)$ & $V_{\mathrm{z}} / \mathrm{F}(\mathrm{L})$ & $\mathrm{CL} / \mathrm{F}(\mathrm{L} / \mathrm{h})$ \\
\hline \multirow{2}{*}{$100 \mathrm{mg}(n=3)$} & 46.5 & 3.00 & 5.18 & 235.0 & 25.1 & 0.374 \\
& $(15.1)$ & $(2.97,6.00)$ & $(25.0)$ & $(14.0)$ & $(4.1)$ & $(18.5)$ \\
$200 \mathrm{mg}(n=4)$ & 25.1 & 3.01 & 7.40 & 244.0 & 27.8 & 0.766 \\
& $(78.4)$ & $(2.02,3.03)$ & $(34.0)$ & $(103.5)$ & $(50.5)$ & $(114.4)$ \\
$300 \mathrm{mg}(n=4)$ & 57.6 & 2.99 & 15.10 & 709.0 & 28.8 & 0.346 \\
& $(24.6)$ & $(1.00,3.05)$ & $(32.4)$ & $(29.0)$ & $(17.2)$ & $(40.6)$ \\
$400 \mathrm{mg}(n=4)$ & 77.9 & 1.98 & 12.70 & 954.0 & 34.2 & 0.305 \\
& $(57.2)$ & $(1.97,4.03)$ & $(12.4)$ & $(18.5)$ & $(13.9)$ & $(40.9)$ \\
$500 \mathrm{mg}(n=3)$ & 97.4 & 1.02 & 22.10 & 1470.0 & 28.5 & 0.203 \\
& $(20.3)$ & $(1.00,2.00)$ & $(25.9)$ & $(39.5)$ & $(31.6)$ & $(50.3)$ \\
\hline
\end{tabular}

* $T_{\max }$ presented as Median (Min, Max) $T_{\max }$ time to peak concentration, $C_{\max }$ peak concentration, $A U C_{0-\mathrm{t}}$ area under the curve from time 0 to last quantifiable concentration, $V / F$ apparent volume of distribution, $C L / F$ apparent total clearance, $C V$ coefficient of variation

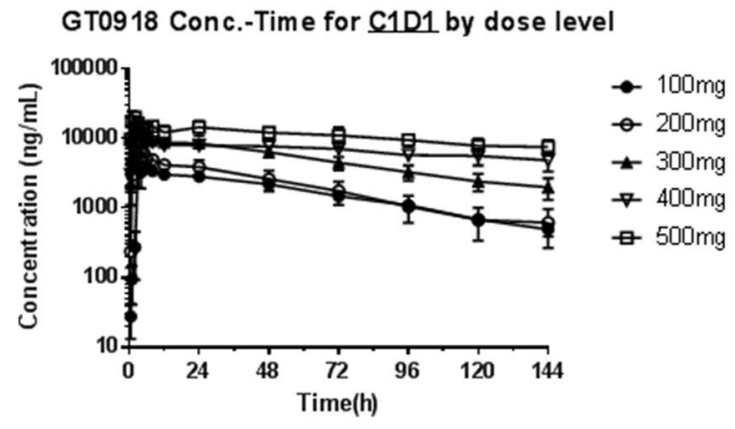

Fig. 3 GT0918 Concentration-Time for C1D1/C1D28 by dose level
GT0918 Conc.-Time for $\mathrm{C} 1 \mathrm{D2} 28$ by dose level

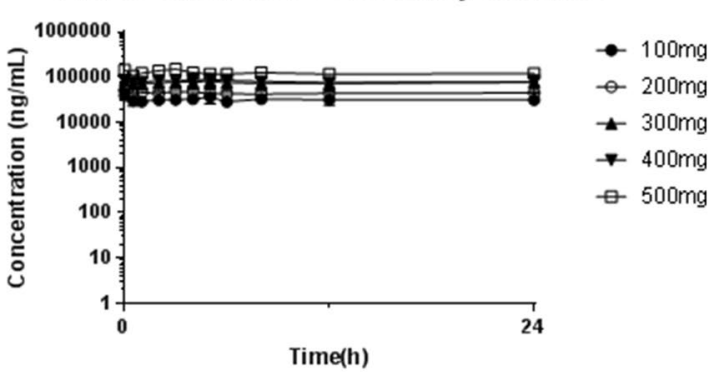


VISIT $=0$, Analyte $=$ GT0918

Rsq $=0.7191$, Intercept $=4.536$, Slope $=0.8559$

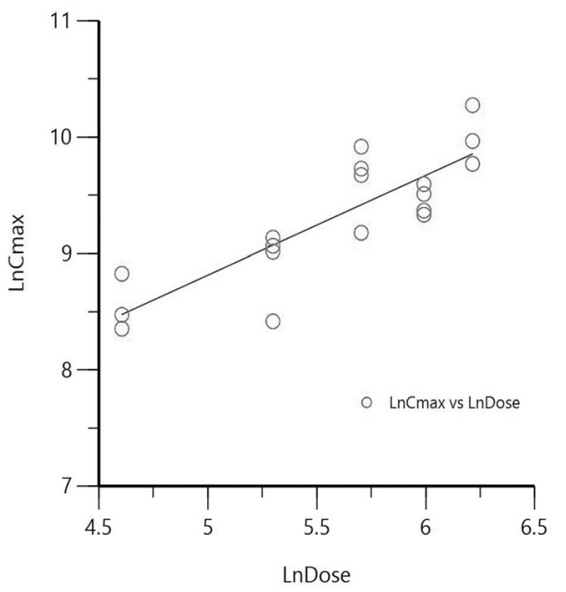

VISIT $=0$, Analyte $=$ GT0918

Rsq $=0.7604$, Intercept $=6.7$, Slope $=0.9427$

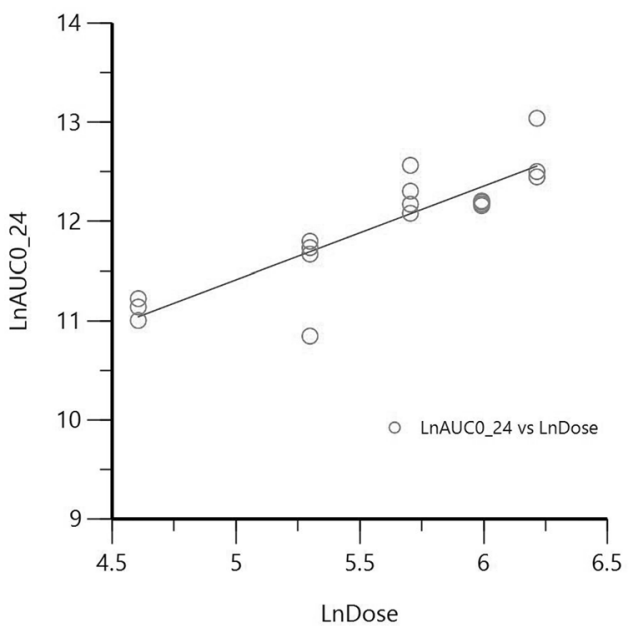

Fig. 4 The relationship between exposure and dose proportionally after a single dose

treatment, and continue treat as of January 20, 2020. The following charts (Fig. 5) illustrated the treatment cycles of patients.

\section{Discussion}

AR has been identified in $60-80 \%$ breast cancer patients (10). Accumulated data have demonstrated the important role of AR-signaling in breast cancer tumorigenesis and disease progression $(8,23)$. Therefore, it is an unmet medical need for clinical development of AR therapies for patients with AR + breast cancers. However, it has not been successful in the clinical studies of AR pathway inhibitors in clinical up to date. The role of AR-signaling may be different among subtypes of breast cancer. Therefore, it is very critical to develop new strategies for clinical studies of AR-targeted therapies for breast cancer and to identify the subgroup that is most likely to benefit from AR-targeting therapies. Here, we disclosed GT0918, a 2nd-generation AR antagonist, for breast cancer treatment.

Our preclinical data demonstrated that GT0918 inhibited the growth of AR-positive breast cancer xenograft tumors. These data support a clinical testing of GT0918 in AR-positive breast cancer tumors.

This phase I study was the first investigation of GT0918 in women with breast cancer. A total of 5 dose levels were tested (100 mg, $200 \mathrm{mg}, 300 \mathrm{mg}, 400 \mathrm{mg}, 500 \mathrm{mg}$ ) in a total of 18 patients. The primary objectives were to characterize the PK properties of GT0918 and to assess the safety and tolerability of GT0918 in order to support further clinical studies in patients with breast cancer.
Results from this clinical study in breast cancer patients proved GT0918 to be well tolerated at a maximum dose of $500 \mathrm{mg} / \mathrm{day}$. And the pharmacokinetics of single- and multiple-dose GT0918 in women with breast cancer was found to be similar to the pharmacokinetics of GT0918 in men with prostate cancer (24). Oral absorption of GT0918, single or multiple doses, were rapid and dose-independent peak concentrations of GT0918 were achieved from 1 to $3 \mathrm{~h}$ postdose. The mean apparent volume of distribution (V/F) of GT0918 in patients ranged from 25.1 to $34.2 \mathrm{~L}$ after a single dose indicating limited extravascular distribution. After a single- or multiple-dose, pharmacokinetics of GT0918 was proportionally correlated with the doses ranging from 100 to $500 \mathrm{mg}$. The mean apparent clearance of GT0918 ranged from 0.203 to $0.766 \mathrm{~L} / \mathrm{h}$, which was approximately $1.5 \%$ of the liver plasma flow rate $(48.7$ $\mathrm{L} / \mathrm{h}$ ), and this suggested that GT0918 is a low extraction ratio drug.

This study demonstrated that GT0918 had an acceptable safety profile in patients with advanced breast cancer, with mild and moderate level of AEs. The most common drug-related adverse events (>15\%) were asthenia (72.2\%), increased blood cholesterol (44.4\%), increased blood triglycerides (33.3\%), anemia (33.3\%), decreased appetite (22.2\%), decreased white blood cell count (22.2\%), increased aspartate aminotransferase $(22.2 \%)$, increased low-density lipoprotein $(22.2 \%)$, increased alanine aminotransferase (16.7\%), weight lost (16.7\%), nausea (16.7\%), and constipation $(16.7 \%)$. The adverse events ( $\geq 3$ Grade) were fatigue $(11.1 \%)$, increased aspartate aminotransferase (5.6\%), increased alanine aminotransferase (5.6\%), and decreased neutrophil count $(5.6 \%)$. 


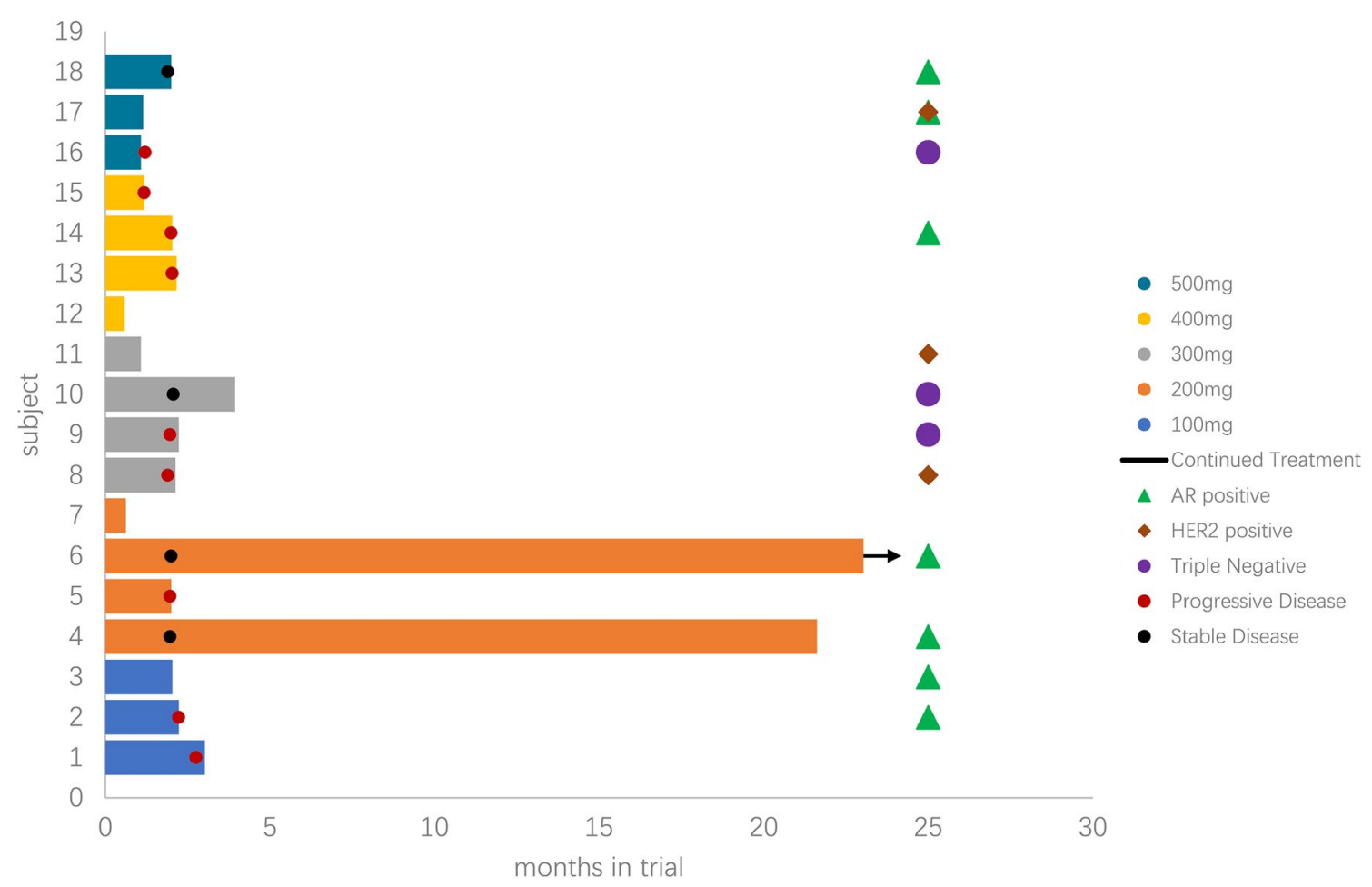

Fig. 5 Swim plot

This incidence of fatigue is similar to the reported fatigue $\mathrm{AE}$ in other studies of AR inhibitors. Importantly, no seizures were observed yet at any dose level.

Preliminary signs of clinical activity of GT0918 in patients with $\mathrm{AR}+\mathrm{mBC}$ were observed. $\mathrm{CBR}$ in 16 weeks was $23.1 \%$ (3/13); among $7 \mathrm{AR}+$ patients, 6 can evaluate efficacy; among AR + patients, CBR in 16 weeks was $33.3 \%$ (2/6) (Fig. 5). Out of the seven confirmed AR + patients, one patient had completed treatment of 23.5 cycles and another patient was still under treatment after completed cycle 25 as of January 20, 2020. Because of the limited sample size of this clinical trial and unrestricted androgen receptor status, one cannot conclude that the patients with high AR expression would have an improved clinical outcome with AR inhibitor treatment. However, it would be interesting to evaluate the efficacy of GT0918 in the expanding clinical studies with AR + patients.

According to the safety, tolerability, and pharmacodynamics analysis, GT0918 shows preliminary signs of clinical activity in AR + breast cancer, thereby warranting further evaluation. Because we did not see 16 weeks response in the $400 \mathrm{mg}$ and $500 \mathrm{mg}$ cohort, two longer duration treatment patients both in $200 \mathrm{mg}$ group obtained 23.5 and 25 cycles and one of the patient had 4.5 cycles in $300 \mathrm{mg}$ group (Fig. 5), and so we consider that lower dose can reach the effective level of treatment. The same phenomenon of GT0918 was also found in prostate cancer (24). As the PK results showed that the drug exposure was increased with dose after a single dose and multiple doses ranging from 100 to $500 \mathrm{mg}$, especially the drug showed linear pharmacokinetics in the dose range of $100-300 \mathrm{mg}$ (Table 3, Fig. 3). Following a single dose, the values of $C_{\max }$ at $200 \mathrm{mg}, 300 \mathrm{mg}$, and $400 \mathrm{mg}$ dosage were $7.4 \mu \mathrm{g} /$ $\mathrm{mL}, 15.1 \mu \mathrm{g} / \mathrm{mL}$, and $12.7 \mu \mathrm{g} / \mathrm{mL}$, respectively (Table 4 , Fig. 3), and after consecutive 28 days administration, the Cmax were $50.9 \mu \mathrm{g} / \mathrm{mL}, 81.0 \mu \mathrm{g} / \mathrm{mL}$, and $82.7 \mu \mathrm{g} / \mathrm{mL}$ (Table 3, Fig. 3). The results indicating that when the dosage was increased from $200 \mathrm{mg}, 300 \mathrm{mg}$ to $400 \mathrm{mg}$, there was no significant increase in drug exposure. At higher dosage, although the exposure increased, it was less than the proportion, indicating that the exposure seems to saturate. The recommended doses for expansion are $200 \mathrm{mg}$ and $300 \mathrm{mg}$ daily, which are similar to GT0918 in prostate cancer.

Based on these results, an expanded/phase Ib and Ic trials have been initiated in patients with AR-positive mBC, being progressed from multiple treatment lines. 


\section{Conclusion}

GT0918, the 2nd-generation AR antagonist, has potential antitumor effect in AR-positive breast cancer. GT0918 is well tolerated with a favorite PK profile and reveals a prospective antitumor activity in AR-positive $\mathrm{mBC}$; the suitable dose of GT0918 was $500 \mathrm{mg}$ QD; the presented results indicate a promising alternative treatment for ARpositive $\mathrm{mBC}$ patients in the future.

Translational Relevance Metastatic breast cancer $(\mathrm{mBC})$ is considered to be incurable and treatment for $\mathrm{mBC}$ still remains to be a great challenge. In recent years, the androgen receptor (AR) pathway has received increased attention as a potential target in breast cancer. This preclinical and phase I clinical trial of GT0918 (proxalutamide) in mBC confirmed that GT0918 can effectively inhibit AR-positive breast cancer tumor growth and to be well tolerated with a favorable PK profile and thus may provide clinical benefits in AR-positive mBC. Additionally, an expanded/phase Ib clinical study in AR-positive mBC is currently underway in China to further evaluate the efficacy and safety of GT0918 (NCT04103853).

Author contributions HL, QZ, YT: Conception and design; GS, HJ, RR, RZ, YL, JZ: Collection and assembly of data; MW, LM, LM, YS: Data analysis and interpretation; All authors: Manuscript writing; All authors: Final approval of manuscript; All authors: Accountable for all aspects of the work.

Funding This study was funded by the National Science and Technology Major Project of the Twelfth Five-Year Plan and the National Science and Technology Major Project of the Thirteenth Five-Year Plan. Authors received no financial support or compensation for this manuscript.

Open Access This article is licensed under a Creative Commons Attribution 4.0 International License, which permits use, sharing, adaptation, distribution and reproduction in any medium or format, as long as you give appropriate credit to the original author(s) and the source, provide a link to the Creative Commons licence, and indicate if changes were made. The images or other third party material in this article are included in the article's Creative Commons licence, unless indicated otherwise in a credit line to the material. If material is not included in the article's Creative Commons licence and your intended use is not permitted by statutory regulation or exceeds the permitted use, you will need to obtain permission directly from the copyright holder. To view a copy of this licence, visit http://creativecommons.org/licenses/by/4.0/.

\section{References}

1. Eileen Tan MH, Li J, Eric Xu H, Melcher K, Yong E-1 (2015) Androgen receptor: structure, role in prostate cancer and drug discovery. Acta Pharmacol Sin 36:3-23. https://doi.org/10.1038/ aps.2014.18

2. Venema CM, Bense RD, Steenbruggen TG, Nienhuis HH, Qiu S-Q, van Kruchten M (2019) Consideration of breast cancer subtype in targeting the androgen receptor. Pharmacol Ther 200:135147. https://doi.org/10.1016/j.pharmthera

3. Birrell SN, Hall RE, Tilley WD (1998) Role of the androgen receptor in human breast cancer. J Mammary Gland Biol Neoplasia 3(1):95-103
4. Toth-Fejel S, Cheek J, Calhoun K, Muller P, Pommier RF (2004) Estrogen and androgen receptors as comediators of breast cancer cell proliferation: providing a new therapeutic tool. Arch Surg 139(1):50-54. https://doi.org/10.1001/archsurg.139.1.50

5. Gucalp A, Traina TA (2016) Targeting the androgen receptor in triple-negative breast cancer. Curr Probl Cancer 40(2):141-150. https://doi.org/10.1016/j.currproblcancer

6. Niemeier LA, Dabbs DJ, Beriwal S, Striebel JM, Bhargava R (2010) Androgen receptor in breast cancer: expression in estrogen receptor-positive tumors and in estrogen receptor-negative tumors with apocrine differentiation. Modern Pathol 23:205-212. https:// doi.org/10.1038/modpathol

7. Collins LC, Cole KS, Marotti JD, Hu R, Schnitt SJ, Tamimi RM (2011) Androgen receptor expression in breast cancer in relation to molecular phenotype: results from the Nurses' Health Study. Modern Pathol 24:924-931. https://doi.org/10.1038/modpathol

8. Rahim B, O'Regan R (2017) AR signaling in breast cancer. Cancers 9(3):21. https://doi.org/10.3390/cancers9030021

9. Rong Hu, Dawood S, Holmes MD, Collins LC, Schnitt SJ, Cole K (2011) Androgen receptor expression and breast cancer survival in postmenopausal women. Clin Cancer Res 17:1867-1874. https:// doi.org/10.1158/1078-0432

10. Kono M, Fujii T, Lim B, Sri Karuturi M, Tripathy D, Ueno NT (2017) Androgen receptor function and androgen receptor-targeted therapies in breast cancer: a review. JAMA Oncol 3:1266-1273. https://doi.org/10.1001/jamaoncol.2016.4975

11. Panet-Raymond V, Gottlieb B, Beitel LK, Pinsky L, Trifiro MA (2000) Interactions between androgen and estrogen receptors and the effects on their transactivational properties. Mol Cell Endocrinol 167:139-150. https://doi.org/10.1016/s0303-7207(00) 00279-3

12. Robinson JLL, MacArthur S, Ross-Innes CS, Tilley WD, Neal DE, Mills IG et al (2011) Androgen receptor driven transcription in molecular apocrine breast cancer is mediated by FoxA1. EMBO J 30:3019-3027. https://doi.org/10.1038/emboj.2011.216

13. Elebro K, Borgquist S, Simonsson M, Markkula A, Jirström K, Ingvar $\mathrm{C}$ et al (2015) Combined androgen and estrogen receptor status in breast cancer: treatment prediction and prognosis in a population-based prospective cohort. Clin Cancer Res 2015(21):3640-3650. https://doi.org/10.1158/1078-0432. ccr-14-2564

14. Clegg NJ, Wongvipat J, Joseph JD, Tran C, Ouk S, Dilhas A et al (2012) ARN-509: a novel antiandrogen for prostate cancer treatment. Cancer Res 72:1494-1503. https://doi.org/10.1158/ 0008-5472

15. Gucalp A, Tolaney S, Isakoff SJ, Ingle JN, Liu MC, Carey LA et al (2013) Phase II trial of bicalutamide in patients with androgen receptor-positive, estrogen receptor-negative metastatic Breast Cancer. Clin Cancer Res 19:5505-5512. https://doi.org/10.1158/ 1078-0432.ccr-12-3327

16. Traina TA, Miller K, Yardley DA, O’Shaughnessy J, Hudis CA (2015) Results from a phase 2 study of enzalutamide (ENZA), an androgen receptor (AR) inhibitor, in advanced AR+ triplenegative breast cancer (TNBC). J Clin Oncol 33:1003. https://doi. org/10.1200/jco.2015.33.15_suppl.1003

17. Elebro K, Borgquist S, Simonsson M, Markkula A, Jirström $\mathrm{K}$, Ingvar $\mathrm{C}$ et al (2015) Combined androgen and estrogen receptor status in breast cancer: treatment prediction and prognosis in a population-based prospective cohort. Clin Cancer Res 21(16):3640-3650. https://doi.org/10.1158/1078-0432. CCR-14-2564

18. Masiello D, Cheng S, Bubley GJ, Lu ML, Balk SP (2002) Bicalutamide functions as an androgen receptor antagonist by assembly of a transcriptionally inactive receptor. J Biol Chem 277:2632126326. https://doi.org/10.1074/jbc.M203310200.(15) 
19. Traina TA, Miller K, Yardley DA, Eakle J, Schwartzberg LS, O'Shaughnessy J et al (2018) Enzalutamide for the treatment of androgen receptor-expressing triple-negative breast cancer. J Clin Oncol 36(9):884-890. https://doi.org/10.1200/JCO.(19)

20. Lehmann BD, Abramson VG, Sanders ME, Mayer EL, Haddad TC, Nanda R et al (2020) TBCRC 032 IB/II multicenter study: molecular insights to AR antagonist and PI3K inhibitor efficacy in patients with $\mathrm{AR}+$ metastatic triple-negative breast cancer. Clin Cancer Res 26(9):2111-2123. https://doi.org/10.1158/1078-0432. CCR-19-2170

21. D'Amato NC, Gordon MA, Babbs B, Spoelstra NS, Carson Butterfield KT, Torkko KC et al (2016) Cooperative dynamics of AR and ER activity in breast cancer. Mol Cancer Res 14(11):10541067. https://doi.org/10.1158/1541-7786.MCR-16-0167

22. Schwartzberg LS, Yardley DA, Elias AD, Patel M, LoRusso P, Burris HA et al (2017) A Phase I/Ib study of enzalutamide alone and in combination with endocrine therapies in women with advanced breast cancer. Clin Cancer Res 23:4046-4054. https:// doi.org/10.1158/1078-0432.ccr-16-2339

23. Kafetzopoulou LE, Boocock DJ, Dhondalay GKR, Powe DG, Ball GR (2013) Biomarker identification in breast cancer: beta-adrenergic receptor signaling and pathways to therapeutic response. Comput Struct Biotechnol J 6:201303003. https://doi.org/10.5936/ csbj.201303003

24. Zhou T, Xu W, Zhang W, Sun Y, Yan H, Gao X et al (2020) Preclinical profile and phase I clinical trial of a novel androgen receptor antagonist GT0918 in castration-resistant prostate cancer. Eur J Cancer 134:29-40. https://doi.org/10.1016/j.ejca.2020.04. 013

Publisher's Note Springer Nature remains neutral with regard to jurisdictional claims in published maps and institutional affiliations. 